\title{
KORELASI PERILAKU CLIPERDIK DETERMINAN PENYAKIT TIDAK MENULAR DIABETES MELETUS DI WILAYAH KERJA PUSKESMAS PANCUR BATU DESA TANJUNG ANOM KECAMATAN PANCUR BATU KABUPATEN DI SERDANG
}

\author{
Magda Siringo-ringo*, Dian Esvani Manurung**, Yisica Oktaviani Manullang** \\ *Staf Pengajar STIKes Santa Elisabeth Medan \\ **Program Studi D III Keperawatan STIKes Santa Elisabeth Medan
}

\begin{abstract}
ABSTRAK
Latar Belakang : Penyakit tidak menular diabetes meletus merupakan kelompok penyakit gangguan metabolic dengan karakteristik kelainan sekresi insulin yang mengakibatkan abnormal karbaohidrat protein lemak yang diakibatkan beberapa faktoryang tidak dapat dirubah (non modificable)yaitu; usia jenis kelamin genetic dan yang dapat dirubah(and modificable./ meliputi. Lingkungan, segi konsumsi kimia gaya hidup yang kurang aktif olahraga/aktifitas fisik obesitas /kegemukan.kurang istirahat tidur, merokok konsumsi makanan yang tinggi kolesterol, stres yang cukup lama berkepanjangan hipertensi darah pengetahuan yang kurang kehamilan.

Tujuan : Tujuan Penelitian untuk menganalisis korelasi antara determinan perilaku dalam hal Cek kesehatan mengenai indeks massa tubuh lingkar perut tensi darah kolesterol).

Metode : Jenis penelitian Explanatory Survey pendekatan cross sectional. Jumlah 66 orang dengan dengan teknik simple random sederhana. Data diperoleh melalui Questionnaires (IPAQ). Diet sehat seimbang menggunakan frequensi food Questionnaires (FFQ). Intrumen kualitas tidur/Pittburg Sleep Quality Index (PSQI) control strees dengan menggunakan Scale Hilminton Anxety rating (HARS) Kejadian Penyakit tidak menular diabetes menggunakan pengukuran glucometer. Analisis data teknik corelatians rank spearmen dan regresi linier sederhana.

Hasil : Hasil penelitian menunjukkan Indeks massa tubuh,lingkar perut. Tensi darah sistolik dan diastolic yang meninggi kadar kolesterol) Rajin olahraga/aktifitas fisik ( $\mathrm{r}=0,847-0.809 ; \mathrm{P}=0.000)$, sedangkan korelasi positif kuat dengan signifikan kuat yaitu; konsumsi karbohidrat, protein lemak ( $\mathrm{r}=0,770 ; \mathrm{P}$ $=0.000$ ), konsumsi serat sayuran buah-buahan dan istirahat tidur korelasi cukup kuat dengan signifikan lemah $(\mathrm{r}=0.289-0.598: \mathrm{P}=0.000,-\& 0.009)$. Kontrol strees tidak memiliki korelasi negative kuat dengan signifikan kuat $(\mathrm{r}-0.457 ; \mathrm{P}=0.000)$ dengan kejadian penyakit tidak menular diabetes meletus. Kesimpulan : Disarankan kepada masyarakat khususnya masyarakat penduduk Dusun VI Desa Tanjung Anom supaya meningkatkan upaya hidup sehat melakukan skrining diabetes di Rumah Sakit, klinik, laboratorium, dan Posbindu.
\end{abstract}

Kata Kunci: Cilperdik, penyakit tidak menular

\begin{abstract}
Bacground : Non-communicable diseases of diabetes eruption are a group of metabolic disorders with characteristics of insulin secretion which results in abnormal fat protein carbohydrates caused by several non-modifiable factors, namely; the age of genetic sex and which can be changed (and modificable./ covers the environment, in terms of consumption of lifestyle chemicals that are less active sports / physical activity obesity/obesity. lack of sleep rest, smoking consumption of foods high in cholesterol, prolonged stress prolonged hypertension blood knowledge that is less pregnancy.

Goals : Research Objectives to analyze the correlation between behavioral determinants in terms of health checks regarding body mass index abdominal circumference blood pressure cholesterol).

Methods : Research type Explanatory Survey cross-sectional approach. The number of 66 people with a simple random technique. Data is obtained through Questionnaires (IPAQ). A balanced healthy diet uses the frequency of the food Questionnaires (FFQ). Sleep quality instrument (Pittsburgh Sleep Quality Index
\end{abstract}


(PSQI) control stress using Scale Hamilton Anxiety rating (HARS). The occurrence of non-communicable diabetes using glucometer measurements. Data analysis of correlation rank spearmen technique and simple linear regression.

Result : The results showed body mass index, abdominal circumference. High blood pressure and systolic and diastolic blood levels) Diligent exercise / physical activity $(r=0.847-0.809 ; P=0.000)$, while strong positive correlation with significant strength is; carbohydrate consumption, fat protein $(r=0.770$; $P=0.000)$, vegetable fruit fiber consumption and sleep rest correlation were quite strong with significantly weak $(r=0.289$ - 0.598: $P=0.000-\& 0.009)$. Strees control did not have a strong negative correlation with a strong significance $(r-0.457 ; P=0.000)$ with the incidence of non-communicable diabetes erupting.

Concultion : It is recommended to the community, especially the Dusun VI residents of Tanjung Anom Village, to increase efforts to live healthy lives in diabetes screening in hospitals, clinics, laboratories, and Posbindu.

Keywords: Cilperdik, non-communicable diseases

\section{PENDAHULUAN}

Penyakit tidak menular (PTM) adalah penyebab kematian terbanyak di Indonesia. Proporsi angka kematian akibat PTM meningkat (Kemenkes, 2011 Sedangkan hasil riset kesehatan dasar 2013 dari $6,9 \%$ penderita yang diperiksa $30,4 \%$ terdiagnosa sebelumnya dan $69,6 \%$ tidak terdiagnosa sebelumnya. Berdasarkan World Health Organization prevalensi penyakit diabetes mellitus di dunia adalah sebesar 4,0\% dan diperkirakan pada tahun 2025 prevalensinya akan meningkat menjadi $5,4 \%$. Di negara maju, jumlah penyakit diabetes mellitus pada tahun 1995 adalah sebesar 51 juta orang dan diperkirakan pada tahun 2025 akan meningkat mencapai 72 juta orang. Sementara itu, di negara sedang berkembang jumlah penderita diabetes mellitus akan meningkat dari 84 juta orang menjadi 228 juta orang. Diperkirakan jumlah tersebut akan naik melebihi 250 juta orang pada tahun 2025 (Wiyono, 2004).

Pengaruh globalisasi di segala bidang, perkembangan teknologi dan industri telah banyak membawa perubahan pada perilaku dan gaya hidup masyarakat serta lingkungannya, misalnya perubahan pola konsumsi makanan, dan berkurangnya aktivitas fisik. Perubahan tersebut tanpa disadari telah memberi kontribusi terhadap terjadinya transisi epidemiologi dengan semakin meningkatnya kasus-kasus penyakit tidak menular seperti Diabetes Mellitus (DM). Prevalensi diabetes di Indonesia berdasarkan
Prevalensi diabetes yang terdiagnosis dokter tertinggi terdapat di DI Yogyakarta $(2,6 \%)$, DKI Jakarta (2,5\%), Sulawesi Utara $(2,4 \%)$ dan Kalimantan Timur (2,3\%). Prevalensi diabetes yang terdiagnosis dokter atau gejala, tertinggi terdapat di Sulawesi Tengah $(3,7 \%)$, Sulawesi Utara (3,6\%), Sulawesi Selatan (3,4\%), Sumatera Utara $(1,8 \%)$ dan Nusa Tenggara Timur 3,3\%.

WHO merekomendasikan bahwa strategi yang efektif perlu dilakukan secara terintegrasi, berbasis masyarakat melalui kerjasama lintas program dan lintas sektor termasuk swasta. .Tujuan program pengendalian diabetes di Indonesia adalah terselenggaranya pengendalian faktor risiko untuk menurunkan angka kesakitan, kecacatan dan kematian penyakit tidak menular. Pengendalian di antara gangguan penyakit metabolik lainnya selain penyakit penyerta seperti hipertensi, jantung koroner dan stroke. "Kementerian Kesehatan saat ini fokus pada pengendalian faktur risiko DM melalui upaya promotif dan preventif dengan tidak mengesampingkan upaya kuratif dan rehabilitatif,"adalah monitoring dan deteksi dini faktor risiko diabetes di Posbindu (Pos Pembinaan Terpadu) penyakit tidak menular dan implementasi perilaku CERDIK dan PATUH" yaitu dengan melakukan: Cek kesehatan secara tetratur untuk mengendalikan berat badan ideal dan tidak beresiko mudah sakit,periksa gula.tensi darah, dan kolesterol secara teratur..Pilar utama penanganan Diabetes Melitus meliputi penyuluhan, perencanaan 
makan,latihan jasmani dan obat. Berdasarkan data World Economic Forum (2015), potensi kerugian akibat Penyakit Tidak Menular di Indonesia pada periode 2012 2030 mencapai 4,47 triliun dolar, atau 5,1 kali PDB 2012. Besarnya pembiayaan kesehatan akibat Diabetes tampak dari klaim BPJS,ternyata Diabetes dan komplikasinya adalah salah satu kelompok klaim terbesar untuk biaya catastrophic JKN,yaitu,33\% dari total pengeluaran. Itulah sebabnya, sebagai agenda genda 2030 dari Sustainable Development Goals (SDGs) menetapkan indikator runtuk mengurangi angka kematian prematur dari Penyakit Tidak Menular salah satunya Diabetes sebanyak sepertiga pada tahun 2030. Diabetes dan komplikasinya membawa kerugian ekonomi yang besar bagi penyandang Diabetes, keluarga mereka, dan Negara, salah satu faktor predominan Diabetes adalah berat badan berlebih dan obesitas. Pola makan kaya kalori, garam, lemak jenuh dan gula, dan rendah serat dapat menyebabkan peningkatan berat badan berlebihan.,kurang aktifitas fisik/olahraga. Maka dalam mengendalika determinan perilaku resiko penyakit tidak menular diabetes meletus dengan CERDIK dan PATUH di wilayah Puskesmas Pancur Batu Desa Tanjung Anom Kabupaten Deli Serdang.

\section{METODE PENELITIAN}

Peneliti melakukan di wilayah kerja Puskesmas Pancur Batu Desa Tanjung Anom Kecamatan Pancur Batu yang dilakukan pada bulan November 2017.Populasi dalam penelitian ini adalah masyarakat laki-laki dan perempuan yang berusia 20 tahun sampai dengan 64 tahun dengan jumlah total populasi 528 orang masyarakat Desa Tanjung Anom yang bertempat tinggal di wilayah Puskesmas Pancur Batu Kecanatan Pancur Batu.

Sampel data inklusi $20-64$ tahun jumlah masyarakat 66 orang. Instrumen yang adalah (1) Angkat/kuesioner yang digunakan dalam memperoleh data skor; enyah merokok, aktifitas fisik /rajin olahraga. Diet sehat seimbang, istirahat tidur yang cukup, kontrole emosi (2) Cek kesehatan. Indeks massa tubuh menggunakan timbangan berat badan, lingkar perut pita pengukur yang mempunyai skala, tensi darah syngnomanometer, kadar glukosa darah menggunakan glukometer.

Pengumpulan data faktor resiko prilaku enyah merokok, aktifitas fisik/rajin olahraga,diet sehat seimbang /pola konsumsi sayur buahbuahan, istirahat tidur yang cukup dan control emosi dilakukan melalui wawancara/ menggunakan kuesioner /angket kepada masyarakat dusun IV Desa tanjung Anom yang datang kelokasi pemeriksaan yang sudah ditentukan berdasarkan informasi yang diberikan peneliti berdasarkan random sampling dan melakukan pemeriksaan fisik klinik dalam hal indeks massa tubuh, lingkar perut,tensi darah serta pemeriksaan kadar glukosa darah dan kolesterol.Data dianalisis menggunakan statistic inferensia correlations yang Speamen Rank(Rho) dan uji korelasi Pearson Scatter Plot (Sugiono,2017) regresi linier sederhana dan berganda.

\section{HASIL DAN PEMBAHASAN}

\section{Korelasi antara Indeks Massa Tubuh dengan Kejadian Penyakit Tidak Menular Diabetes}

ScatterPlot menggambarkan bahwa data cenderung mendekati sudut garis linier positip. Hal ini menunjukkan bahwa korelasi antara indeks massa tubuh dengan kejadian penyakit tidak menular diabetes meletus. Untuk melihat korelasinya sangat kuat, dapat dilihat dari hasil uji korelasi Product Moment dari Pearson yaitu; (r:0.809; p: 0.000) yang menunjukkan bahwa korelasi sangat positif dan signifikan antara indeks massa tubuh akan meningkat kadar glukosa dalam darah penduduk dusun VI DesaTanjung Anom sehingga akan berisiko mengalami. kejadian penyakit tidak menular diabetes .

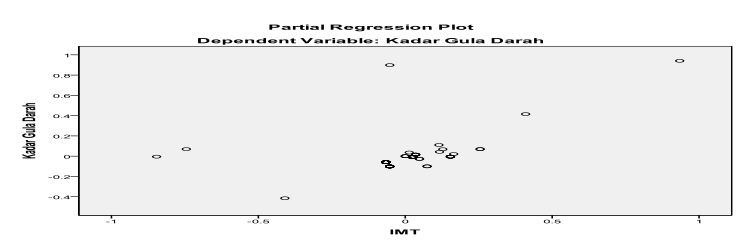

Gbr.1 Korelasi antara Indeks massa Tubuh dengan Kejadian Diabetes Meletus. $(r=0.809 ; P=0.000)$

Hasil penelitian indeks massa tubuh masyarakat dusun VI Desa Tanjung Anom tergolong kurang atau disebut obesitas derajat 
satu $(77.3 \%)$, namun masih didapati penduduk yang indeks massa tubuhnya batas normal adalah $18.5-27.5 \mathrm{~kg} / \mathrm{m}^{2}$ sebanyak $(22.7 \%)$ Peningkatan berat badan dan obesitas merupakan penyumbang utama dalam perkembangan kadar gula darah sehingga dapat menyebabkan diabetes melitus.

Kolrelasi Antara IMT dengan diabetes ada penelitian ini, hasil menyebutkan sebanyak 51 responden $(77.3 \%)$, memiliki IMT yang dikategorikan gemuk dan hanya 15 responden $(22.7 \%)$ yang dikategorikan normal.. Berdasarkan hasil analisis uji korelasi product moment ditemukan adanya korelasi sangat kuat yang signifikan antara IMT dengan kejadian diabetes melitus berdasarkan nilai (r:0.809;p:0.000),

Faktor risiko mayor adalah obesitas atau berat badan lebih (IMT> $27.5 \mathrm{~kg} / \mathrm{m} 2$.Indeks masa tubuh secara bersama-sama adalah kelompok obesitas 14 kali lebih besar dibandingkan dengan kelompok IMT normal. Penelitian menurut Sunjaya (2009) menemukan bahwa individu yang mengalami obesitas mempunyai risiko2.7.kali lebih besar untuk terkena diabetes mellitus dibandingkan dengan individu yang tidak mengalami obesitas.

\section{Korelasi Antara Lingkar Pinggang dengan Kejadian Diabetes Meletus}

ScatterPlot gambar 1 menggambarkan bahwa data cenderung mendekati sudut garis linier positip. Hal ini menunjukkan bahwa korelasi antara indeks massa tubuh dengan kejadian penyakit tidak menular diabetes meletus. Untuk melihat korelasinya sangat kuat, dapat dilihat dari hasil uji korelasi Product Moment dari Pearson yaitu; (r: 0.809;p: 0.000) yang menunjukkan bahwa korelasi sangat positif dan signifikan antara indeks massa tubuh akan meningkat kadar glukosa dalam darah

masyarakat dusun VI DesaTanjung Anom sehingga akan berisiko mengalami. kejadian penyakit tidak menular diabetes meletus

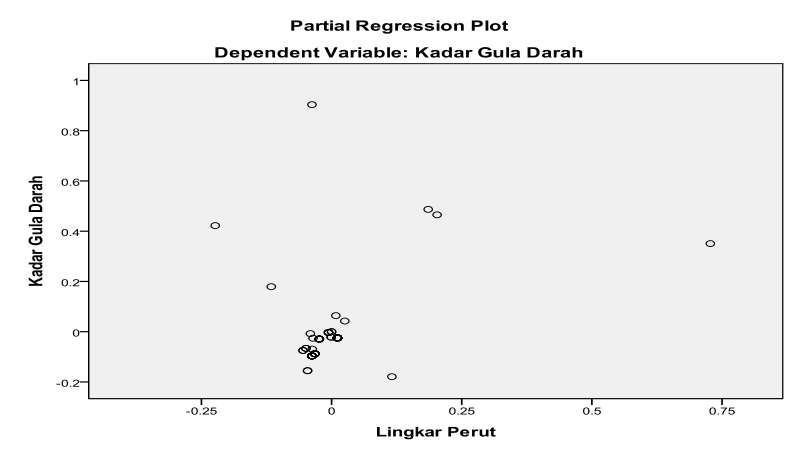

Gbr 2.Korelasi Antara Lingkar Pinggang dengan Kejadian Diabetes Meletus ( $r=0.809 ; P=0.000)$.

Berdasarkan kategori usia, rata- rata berusia 20 - 40 tahun tahun pada laki-laki dan perempuan. Rata-rata lingkar pinggang $93,18 \mathrm{~cm}$ pada lakilaki dan $87,32 \mathrm{~cm}$ pada perempuan. Hasil analisis uji korelasi Product Moment dari Prearson menunjukkan bahwa korelasi sangat kuat dengan signifikan (r:0.809;p:0.000). kadar kolestrol yang tinggi berisiko terjaadi penyakit tidak menular diabetes Kadar kolestrol tinggi menyebabkan meningkatnya asam lemak bebas sehingga terjadi lipotoksisity. Hal ini akan menyebabkan terjadinya kerusakan sel beta pankreas yang akhirnya mengakibatkan diabetes (Kemenkes,2010).

Lingkar perut digunakan untuk menentukan menentukan obesitas sentral dan komplikasi metabolik yang terkait.. Kriteria ukuran lingkar pinggang untuk etnis Asia Selatan yaitu kelompok laki-laki > $90 \mathrm{~cm}$, sedangkan kelompok perempuan $>80 \mathrm{~cm}$ yang dapat dikatakan beresiko komplikasi metabolik salah satunya dislipidemia.

Berdasarkan hasil pengumpulan data diketahui bahwa kebanyakan penduduk dusun VI memiliki profil lipid yang kurang baik. Dimana 52 orang $(78.8 \%)$ kadar kolesterol total $\geq 190 \mathrm{mg} / \mathrm{dl}$ dan 14 orang $(21.2 \%)$ memiliki kadar kolesterol kurang dari $\leq 190 \mathrm{mg} / \mathrm{dl}$. Berdasarkan kategori usia, ratarata sampel yang didapat berusia 58,18 tahun pada laki-laki dan usia 53,68 tahun pada perempuan.rata-rata lingkar pinggang 93,18 $\mathrm{cm}$ pada laki-laki dan $87,32 \mathrm{~cm}$ pada perempuan. Lingkar perut digunakan untuk menentukan obesitas sentral. Lingkar pinggang dikatakan sebagai indeks yang berguna untuk menentukan obesitas sentral dan 
komplikasi metabolik yang terkait.. Kriteria ukuran lingkar pinggang untuk etnis Asia Selatan yaitu kelompok laki-laki > $90 \mathrm{~cm}$, sedangkan kelompok perempuan $>80 \mathrm{~cm}$ yang dapat dikatakan beresiko komplikasi metabolik salah satunya dislipidemia. Hasil pengumpulan data diketahui bahwa 28,3\% laki-laki memiliki lingkar pinggang $\geq 90 \mathrm{~cm}$ dan sementara $43,4 \%$ sampel perempuan memiliki lingkar pinggang $\geq 80 \mathrm{~cm}$,

\section{Korelasi Antara Kolesterol dengan Kejadian Diabetes}

ScatterPlot gambar 3 menggambarkan bahwa data cenderung berkumpul pada garis linier positip. Hal ini menunjukkan bahwa korelasi antara determinan kolesterole dengan kejadian penyakit tidak menular diabetes meletus. Untuk melihat korelasinya sangat kuat, dapat dilihat dari hasil uji korelasi Product Moment dari Pearson yaitu; $(\mathrm{r}=0.844$; $\mathrm{P}=0.00$ ),yang menunjukkan bahwa korelasi sangat kuat positif dan signifikan antara kolesterol .Hal ini berarti apabila kolesterol meningkatkan kadar glukosa dalam darah penduduk dusun VI DesaTanjung Anom sehingga akan berisiko mengalami kejadian penyakit tidak menular diabetes meletus mengalami kejadian penyakit tidak menular diabetes meletuS

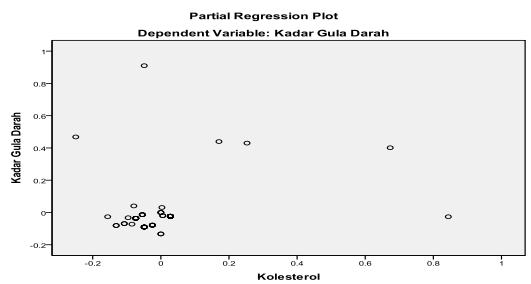

Gambar 3.Korelasi antara Kolesterol dengan Kejadian Penyakit Tidak Menular Diabetes Meletus $;(r=0.844 ; P=0.00)$

Berdasarkan hasil penelitian menunjukkan bahwa tekanan darah sistolik dan diastolic yang didapatkan sebanyak 52 orang $(78.8 \%)$ masuk dalam kategori hipertensi, kemudian kategori prehipertensi sampai dengan batas normal sebanyak14 orang (21.2\%) dilaksanakan uji korelasi Product Moment dari Pearson menunjukkan bahwa korelasinya sangat kuat $(\mathrm{r}=0.847 ; \mathrm{P}=0.000)$. Pada orang dengan diabetes,kenaikan tensi darah berhubungan dengan resistensi insulin dan abnormalitas pada sistem renin-angiotensin dan konsekuensi metabolik yang meningkatkan morbiditas. Hiperglikemia menghambat produksi endothelium, mesintesis aktivasi dan meningkatkan produksi superoksid anion yaitu sebuah spesies oksigen reaktif yang merusak formasi nitrit oksida,korelasi antara kadar kolesterol yang tinggi dengan tekanan darah saat kadar kolesterol seseorang naik atau menjadi tinggi ia menderita tekanan darah yang menjadi meningkat pula atau hipertensi.

Hasil penelitian menunjukan bahwa orang yang terkena hipertensi berisiko lebih besar untuk menderita diabetes, dengan odds 6,85 kali lebih besar dibanding orang yang tidak hipertensi. Penelitian menurut Sunjaya (2009) menemukan bahwa individu yang mengalami hipertensi mempunyai risiko 1,5 kali lebih besar untuk mengalami diabetes dibanding individu yang tidak hipertensi. Beberapa literatur mengaitkan hipertensi dengan resistensi insulin. Pengaruh hipertensi terhadap kejadian diabetes melitus disebabkan oleh penebalan pembuluh darah arteri yang menyebabkan diameter pembuluh darah menjadi menyempit. (Zieve, 2012)..

\section{Korelasi antara Tensi darah dengan Kejadian Penyakit Tidak Menular Diabetes Meletus}

ScatterPlot gambar 3 menggambarkan bahwa data cenderung berkumpul pada garis linier positip. Hal ini menunjukkan bahwa korelasi antara determinan tensi darah dengan kejadian penyakit tidak menular diabetes meletus. Untuk melihat korelasinya sangat kuat, dapat dilihat dari hasil uji korelasi Product Moment dari Pearson yaitu;(r:0.847;P:0.00), menunjukkan bahwa korelasinya sangat kuat positif dan signifikan dengan tensi darah .Hal ini berarti apabila sistolik lebih dari $120 \mathrm{mmHg}$ dan diastolic lebih dari $80 \mathrm{mmHg}$ yang dikatakan dengan hipertensi sehingga akan meningkatkan kadar glukosa dalam darah penduduk dusun VI DesaTanjung Anom sehingga akan berisiko mengalami kejadian penyakit tidak menular diabetes meletus. 


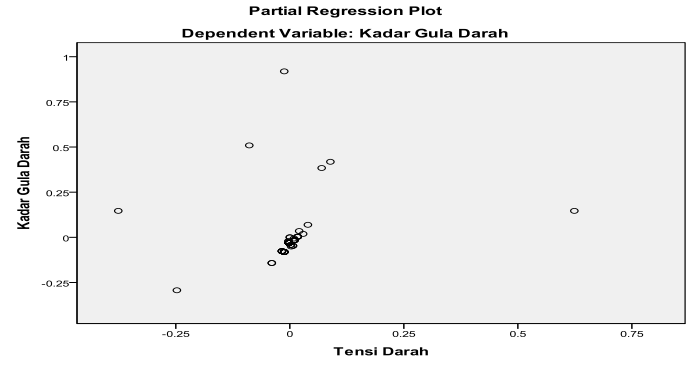

Gbr 4. Korelasi antara determinan Tensi darah dengan Kejadian Penyakit Tidak MenularDiabetes Meletus ;(r= $0.847 ; \mathrm{P}=0.00)$,

\section{Korelasi Merokok dengan Kejadian Diabetes Meletus}

ScatterPlot gambar 4 menggambarkan bahwa data cenderung menjauh membentuk sudut mendatar pada garis linier negatif. Hal ini menunjukkan bahwa korelasi antara determinan enyah merokok/sering dekat dengan perokok kejadian penyakit tidak menular diabetes meletus. hasil uji korelasi Product Moment dari Pearson yaitu; $(\mathrm{r}=0.098 ; \mathrm{P}=0.216)$, menunjukkan bahwa korelasi sangat lemah dan tidak signifikan dengan kejadian penyakit tidak menur diabetes meletus.,masyarakat dusun VI DesaTanjung Anom yang tidak merokok dan jauh dari perokok tidak akan berisiko mengalami kejadian penyakit tidak menular diabetes meletus

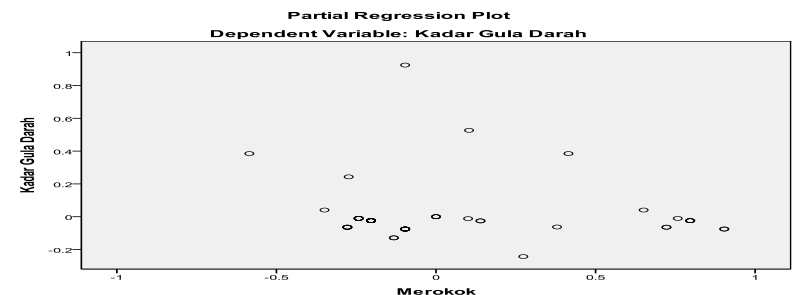

Gbr 5.Korelasi Enyah Merokok dengan Kejadian Penyakit Tidak MenularDiabetes Meletus; $(r=0.098 ; P=0.216)$

Perilaku enyahkan merokok /sering dekat perokok masyarakat dusun VI Desa Tanjung Anom sebanyak 52 orang $(78.8 \%)$ dan 14 orang saja tidak merokok (21.2\%).Dengan uji product Moment dari Pearson korelasi perokok /sering dekat perokok sangat lemah dengan tidak kurang signifikan( $\mathrm{r}=0.098 ; \mathrm{P}=0.216)$ dengan kejadian penyakit tidak menular diabetes meletus/ perokok aktif dan orang yang sering terpapar dengan asap rokok memiliki risiko yang signifikan terhadap diabetes jika dibandingkan dengan orang yang tidak pernah merokok..Ada beberapa peneliti memperkirakan bahwa $11.7 \%$ dari kasus diabetes pada pria dan $2.4 \%$ kasus diabetes pada wanita di dunia (27.8 juta kasus) berhubungan langsung dengan aktivitas merokok.

Perokok pasif, meskipun hanya menghirup asapnya juga ternyata mengalami peningkatan risiko sebanyak 22\%.dan mempelajari bagaimana penurunan risiko diabetes terjadi setelah seseorang berhenti merokok. Hasil analisis univariat menunjukn distribusi responden berdasarkan terpapar asap rokok dan tidak terpapar asap rokok hampir merata. Responden yang terpapar asap rokok merupakan perokok aktif dan pasif.

Penelitian oleh Houston mendapatkan bahwa perokok aktif memiliki risiko $76 \%$ lebih tinggi untuk terserangdisbetes dibanding dengan yang tidak terpajan (Irawan,2010). Kadar kolestrol yang tinggi berisiko terhadap penyakit tidak menualar diabetes Kadar kolestrol tinggi menyebabkan meningkatnya asam lemak bebas sehingga terjadi lipotoksisity. Hal ini akan menyebabkan terjadinya kerusakan sel beta pankreas yang akhirnya mengakibatkan diabetes (Kemenkes, 2010).

\section{Korelasi Antara Rajin Olahraga/Aktifitas Fisik dengan Kejadian Diabetes.}

ScatterPlot;gambar;5 menggambarkan bahwa data cenderung berkumpul pada garis linier positip. Hal ini menunjukkan bahwa korelasi antara determinan dengan kejadian penyakit tidak menular diabetes meletus. Untuk melihat korelasi sangat kuat, dapat dilihat dari hasil uji korelasi Product Moment dari Pearson yaitu;(r:809;P:0.000),yang menunjukkan bahwa korelasi sangat kuat positif dan signifikan dengan rajin olahraga/aktifitas fisik .Hal ini berarti apabila tidak melakukan aktifitas dan tidak rajin olahraga sehingga akan terganggu dalampengaturan kadar gula darah penduduk dusun VI DesaTanjung Anom sehingga akan berisiko mengalami kejadian penyakit tidak menular diabetes meletus. 


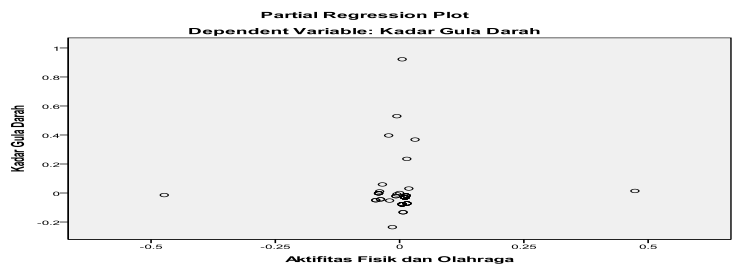

Gbr:6.Korelasi antara Determinan Rajin OLahraga/Aktifitas Fisik dengan Kejadian Penyakit Tidak MenularDiabetes Meletus $(r=809 ; P=0.000)$.

Penelitian ini dilaksanakan di dusun VI

Desa Tanjung Anom ditemukan bahwa masyarakat jarang olahraga /melakukan aktifitas fisik ditemukan sebanyak 53 orang dari 66 orang kurang melaksanakan aktifitas fisik olahraga hanya sedikit mengeluarkan kalori energy dalam satu hari- minggu antara kurang dari 600 Met/minggu.dapat dikategorikan ringan dilaksanakan uji korelasi Product Moment dari Pearson menunjukkan bahwa korelasi sangat kuat dengan signifikan (r:0.809;p:0.000) dengan kejadian penyakit tidak menular diabetes meletus..

Aktivitas fisik secara teratur dapat secara dramatis meningkatkan kondisi penderita diabetes Jenis olahraga dapat dilakukan, namun disarankan untuk menjagaintensitas sedang. olahraga tidak harus yang sulit atau rumit. Selain mejaga kadar gula darah, olahraga juga membantu mengurangi keparahanpenyakit.

Berolahraga dapat sangat membantu dalam mengurangi risiko komplikasi jangka panjang. tingkat gula darah normal adalah 100 miligram per desiliter ( $\mathrm{mg} / \mathrm{dl}$ ). Pada tahap pra-diabetes dapat berkisar dari $100 \mathrm{mg} / \mathrm{dl}$ menjadi $125 \mathrm{mg} /$ dl. Orang yang menderita diabetes memiliki 126 $\mathrm{mg} / \mathrm{dl}$ atau lebih tinggi.Hasil ini sesuai dengan dasar teori yang menyatakan bahwa selama aktivitas fisik/olahraga, terjadi peningkatan masukan glukosa ke otot dikarenakan adanya insulin independent yang mempengaruhi terjadinya peningkatan jumlah transporter GLUT-4 pada membrane sel dan terjadi selama beberapa jam setelah aktivitas atau lebih panjang lagi disertai peningkatan sensitivitas insulin dengan aktivitas yang tetap.

Hasil penelitian ini sejalan dengan penelitian sebelumnya yang dilakukan oleh Gumilang Paramitha (2013) dalam penelitian yang berjudul hubungan aktivitas fisik dengan kadar gula darah pasien diabetes di RS
Karanganyar dimana aktivitas fisik yang sedang dan teratur dapat mengontrol kadar gula darah mendekati batas normal. Penelitian yang lain juga dilakukan Vienna Worang (2013. .Aktivitas olahraga sangat berpengaruh terhadap pengendalian kadar gula darah. Melakukan olahraga yang baik dan teratur membuat peningkatan aliran ke otot dengan cara pembukaan kapiler (pembuluh darah kecil diotot) dan hal ini akan menurunka tekanan pada otot yang pada gilirannya akan meningkatkan penyediaan dalam jaringan otot itu sendiri. Dengan demikian akan mengurangi gangguan metabolisme karbohidrat pada penderita diabetes mellitus sehingga menurunkan kadar glukosanya (Wirato, 2013 dalam Saliadeho, 2016).

Korelasi Diet Sehat Seimbang /Pola Konsumsi Sayur dan Buah-Buahan dengan Kejadian Diabetes

Scatter Plot pada gambar 6 menggambarkan bahwa data cenderung berkumpul pada garis linier positip. Hal ini menunjukkan bahwa korelasi antara determinan konsumsi karbohidrata dengan kejadian penyakit tidak menular diabetes meletus. Untuk melihat korelasi sangat kuat, dapat dilihat dari hasil uji korelasi Product Moment dari Pearson yaitu;(r:0770p: 0.000) yang menunjukkan bahwa korelasi positif kuat dan signifikan dengan diet sehat seimbang komsumsi karbohidrat.Hal ini berarti apabila frekuensi konsumsi karbohidrat sering setiap hari lebih lima kali sehari akan terganggu hormone glikemik tubuh sehingga akan terganggu dalam pengaturan kadar gula darah penduduk dusun VI DesaTanjung Anom sehingga akan berisiko mengalami kejadian penyakit tidak menular diabetes meletus.

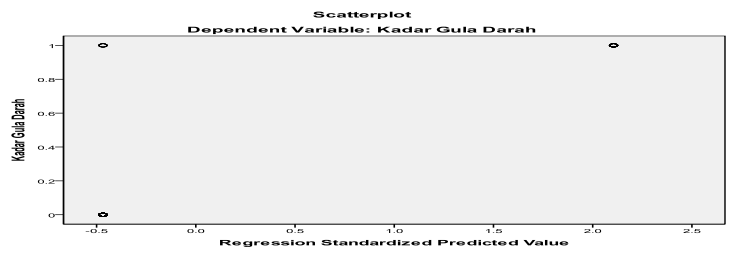

Gbr 7. Korelasi antara Diet Sehat Seimbang Karbohidrat dengan Kejadian Penyakit Tidak MenularDiabetes Meletus(r= 0770; P;0.000)

Penelitian ini, menunjukkan ditemukan bahwa masyarakat Dusun VI Desa Tanjung 
Anom sebanyak 54 orang (78.8\%) dalam pengaturan diet yang sehat seimbang dimana frekuensi konsumsi karbohidrat protein lemak paling sering durasi lebih dari lima kali perhari.sedang yang dapat konsumsi kurang dari lima kali per hari sebanyak 12 orang (18.2\%), dan penduduk dusun VI dalam pengaturan sehat seimbang tentang konsumsi serat sayuran dan buah - buahan jarang konsumsi sebnyak 52 orang dari 66 kurang jarang konsumsi sayur dan buah (78.8\%). Dilaksanakan uji korelasi Product Moment dari Pearson menunjukkan bahwa korelasi kuat dengan sangat signifikan $(\mathrm{r}=0.770 ; \mathrm{p}=0.000)$.).

Berbeda dengan penelitian Yekti (2014) yang menyatakan bahwa konsumsi karbohidrat korelasi kuat dan bermakna dengan kadar glukosa darah puasa. korelasi ini bersifat positif sehingga semakin tinggi jumlah karbohidrat yang dikonsumsi dari makanan utama dan selingan lebih penting dari daripada sumber atau tipe karbohidrat tersebut. Semua responden masyarakat dusun VI mengkonsumsi nasi sebagai sumber karbohidrat utama sedangkan sumber karbohidrat lainnya adalah kentang dan singkong. mengkonsumsi nasi sebagai sumber karbohidrat utama dengan frekuensi lebih lima kali dalam sehari dengan persentase sebesar $78,8 \%$. Melalui uji korelasi Spearman dengan alfa $(\alpha) 5 \%$, didapatkan signifikansi sebesar 0,770.rrtinya kuat korelasi antara konsumsi nasi dengan meningkatkan kadar gula darah .

Hal ini mungkin dikarenakan responden tidak membatasi frekuensi makan harian meskipun membatasi porsi nasi dalam sekali makan Perilaku penduduk dusun VI Desa Tanjung Anom frekuensin sering lebih dari lima kali per hari sejumlah 54 orang(78.8\%) dengan sumber protein dari hewani daging merah,mengkonsumsi protein sebanyak 12 responden $(21.2 \%)$ sumber dari ikan nabati dengan porsi 2-3 kali perhari. Hasil uji statistik menunjukkan nilai $\mathrm{p}=0,00 \mathrm{r} ; 0.00$ dapat diartikan korelasi kuat dengan signifikan antara konsumsi protein dengan terjadinya diabetes mellitus. dengan konsumsi protein sebagian besar yaitu $78.8 \%$ memiliki kadar gula darah tidak terkontrol dibandingkan dengan yang memiliki kadar gula darah terkontrol $21.2 \%$. Selain itu, defisiensi asam amino terutama sistein dan taurin menyebabkan peningkatan level insulin tertkait dengan stress yang disebabkan oleh tidak terpenuhinya asam amino yang bekerja sebagai neurotransmitter di otak. Korelasi kuat sangat bermakna tingkat asupan protein dengan kontrol kadar gula darah dikarenakan fungsi utama protein adalah untuk pertumbuhan dan mengganti sel-sel yang rusak. Protein akan digunakan sebagai sumber energi apabila ketersediaan energi dari sumber lain yaitu karbohidrat dan lemak tidak mencukupi melalui proses glikoneogenesis..

Penelitian ini, diketahui pada pemeriksaan ditemukan data bahwa kolesterol responden penduduk berjumlah 52 orang $(78.8 \%)$ meningkat yang memiliki asupan lemak sesuai dengan kebutuhan sebagian besar memiliki kadar gula darah tidak terkontrol yaitu sebanyak $84.8 \%$, hal tersebut dikarenakan walaupun asupan lemak baik namun asupan energi lebih dari kebutuhan yang bersumber dari karbohidrat dan beban glikemik. Olahraga pun dapat melancarkan peredaran darah dan meningkatkan sensitivitas insulin. Hasil penelitian ini responden mengkonsumsi yang sumber lemak frekuensinya lebih lima kali sehari dari beberapa mengungkapkan bahwa jajanan /snack selalu disertakan gorengan dan pengolahan makanan selalu menggunakan santan, minyak sebanyak 52 orang $(78.8 \%)$. Lemak merupakan salah satu unsur yang terdapat dalam makanan. Korelasi tingkat kecukupan lemak dengan kadar glukosa darah.

Hasil pengamatan selama dua hari di dusun VI Desa Tanjung Anom bahwa penduduk menunjukkan bahwa rerata mengonsumsi makanan yang mengandung lemak banyak berasal dari lauk pauk seperti semur ayam, tahu goreng, tahu semur, telur mata sapi, dan kerupuk serta selingan seperti bihun goreng. Penelitian ini sejalan dengan penelitian Raditya 2014 yang mengatakan bahwa tidak ada hubungan yang bermakna tingkat asupan lemak dengan kadar glukosa darah responden.

Penelitian ini, menunjukkan bahwa penduduk dusun Vi Desa Tanjung Anom dalam perilaku konsumsi sayur buah-buahan jarang 
berjumlah 52 orang $(78.8 \%)$ tergolong kurang . selainnya 14 orang saja adanya perilaku konsumsi serat sayur dan buah-buahan. Korelasi antara asupan serat sayuran buah dengan kadar glukosa harah Hasil penelitian menunjukkan rerata responden mengonsumsi asupan serat sebesar $21.2 \%$ mengkonsumsi sayur buah 3-5 porsi.per hari. Hasil uji statistik yang telah dilakukan peneliti dengan menggunakan korelasi rank spearman menunjukkan bahwa kuat korelasi dengan signifikan antara asupan serat dengan kadar glukosa darah responden dengan nilai (p:0.000:r:0.589).

Hasil penelitian menunjukkan sebagian pasien diabetes dengan kadar gula darah tidak terkontrol memiliki tingkat konsumsi sayuran yang tidak baik dari kebutuhan yaitu sebesar $97,1 \%$ dan hanya $2,9 \%$ pada pasien yang kadar gula darah terkontrol. Uji fisher's exact test menyatakan ada hubungan yang bermakna konsumsi sayuran dengan kontrol kadar gula darah. Adanya hubungan konsumsi sayuran dengan kontrol kadar gula darah pada pasien diabetes dapat dijelaskan bahwa dengan konsumsi serat sesuai kebutuhan dapat menimbulkan rasa kenyang akibat masuknya karbohidrat komplek yang menyebabkan menurunnya selera makan dan akhirnya menurunkan konsumsi makan, disamping itu serat juga mengandung kalori rendah sehingga dapat menurunkan kadar gula darah dan lemak dalam tubuh.

Seseorang yang konsumsi serat $<11,96$ g/hari berisiko 9,5 kali lebih besar untuk menderita pra-diabetes daripada mereka yang mengkonsumsi serat $\geq 11,96 \mathrm{~g} /$ hari. Korelasi konsumsi serat dengan kejadian pra-diabetes tersebut tidak dipengaruhi oleh faktor keturunan. Pada dasarnya, semua subjek penelitian ini berada pada kondisi berisiko mengalami pradiabetes karena pola konsumsi serat yang lebih rendah dari $25 \mathrm{~g} /$ hari dikontrol oleh faktor konsumsi lemak, dan konsumsi serat. Faktor keturunan tidak berpengaruh pada hubungan antara aktivitas fisik dengan kejadian pradiabetes. Seseorang yang dengan aktivitas fisik < 120 menit per hari berisiko 13,7 kali lebih besar untuk mengalami pra-diabetes daripada orang yang dengan aktivitas fisik $\geq 120$ menit per hari. Peningkatkan aktivitas fisik akan berisiko rendah menderita diabetes .

\section{Korelasi Istirahat Tidur dengan Kejadian Diabetes}

ScatterPlot pada gambar 10 menggambarkan bahwa data cenderung berkumpul menjauh pada garis mendatar linier positip. Hal ini menunjukkan bahwa korelasi antara determinan istirahat tidur dengan kejadian penyakit tidak menular diabetes meletus. Untuk melihat korelasi cukup dan signifiakan, dapat dilihat dari hasil uji korelasi Product Moment dari Pearson yaitu;(r:0.289:p:0.000),yang menunjukkan bahwa korelasi positif cukup kuat dan signifikan istirahat tidur ..Hal ini berarti apabila seseorang cukup istirahat tidur kecil kemungkinan tidak akan terganggu dalam pengaturan kadar gula darah penduduk dusun VI DesaTanjung Anom sehingga akan berisiko mengalami kejadian penyakit tidak menular diabetes meletus

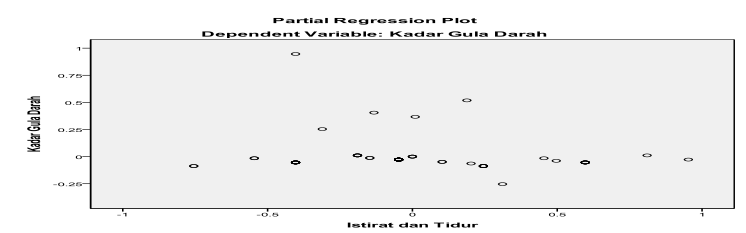

Gbr 8. Korelasi antara Istirahat Tidur dengan Kejadian Penyakit Tidak Menular Diabetes Meletus $(r=0.289$; $\mathbf{P}=\mathbf{0 . 0 0 0 )}$

Penelitian pada masyarakat dusun VI Desa Tanjung Anom dalam hal istirahat dan tidur kurang durasi kualitas sebanyak 44 orang $(66.7 \%)$ dan 22 orang dengan istirahat tidur cukup (33.3\%). Dengan uji Produc Moment dari Pearson menunjukkan korelasi cukup lemah signifikan $(\mathrm{r}=0.289 ; \mathrm{P}=0.009)$ dengan kejadian penyakit diabetes .

Jika dibiarkan lama-lama tentu akan berakibat buruk. Padahal ketika kita tidak tidur maka kelelahan yang sangat dan konsentrasi akna jauh berkurang. Untuk mengurangi rasa ngantuk di pagi hari maka sangat disarankan bagi Anda untuk tidur minimal 7-8 jam setiap harinya. Dengan jumlah tidur 7-8 jam sehari dianggap merupakan jumlah jam tidur yang baik dan menyehatkan tubuh. Terlalu lama tidur (>8 jam) juga tidak baik bagi tubuh karena bisa 
memicu gangguan metabolisme tubuh yakni salah satunya diabetes. Penurunan toleransi glukosa dapat terjadi sela periode tidur dapat meningkatkan kadar glukosa darah dengan meningkatnya berkisar antara 20-30\% dan dapat meningkatkan kadar glukosa darah maksimal terjadi pada saat tidur.

Hasil penelitian Pereira (2009) tentang kualitas tidur yang diakibatkan nokturia. Kebutuhan kualitas tidur istirahat kurang cukup metabolism terganggu. Hasil riset para ahli dari unuversiti of chicago mengungkapkan kurang tidur selama 3 hari mengakibatkan kemampuan tubuh memproses glikosa menurun dratis. artinya risiko diabetes meningkat. Kurang tidur juga sejenis hormon dalam darah yang memic nafsu makan.mendorong rasa lapar penderita gangguan tidur terpicu menyantap makanan berkalori.

\section{Korelasi Kontrol Strees dengan Kejadian Diabetes}

ScatterPlot pada gambar 11 menggambarkan bahwa data cenderung berkumpul menjauh pada garis mendatar linier negative.. Hal ini menunjukkan bahwa korelasi antara determinan dalam mengontrole strees dengan kejadian penyakit tidak menular diabetes meletus. Untuk melihat korelasi negative cukup kuat dan signifiakan, dapat dilihat dari hasil uji korelasi Product Moment dari Pearson yaitu;(r: 0.457 ;p:0.000) yang menunjukkan bahwa korelasi negatif cukup kuat dan signifikan dalam kontrole trees..Hal ini berarti apabila seseorang dapat mengontrole streesnya kemungkinan tidak akan terganggu dalam pengaturan kadar gula darah penduduk dusun VI DesaTanjung Anom sehingga akan berisiko mengalami kejadian penyakit tidak menular diabetes meletus.

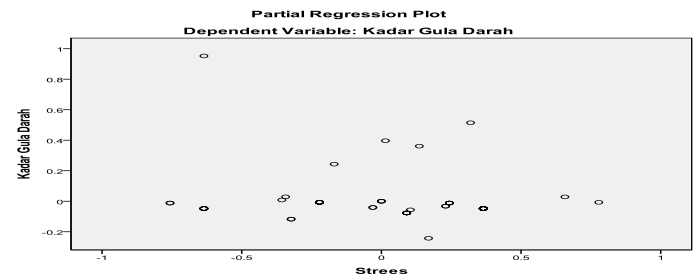

Gbr ;9: Korelasi antara Kontrole Strees dengan Kejadian Penyakit Tidak Menular Diabetes Meletus $(\mathrm{r}=\mathbf{- 0 . 4 5 7} ; \mathrm{P}=\mathbf{0 . 0 0 0})$
Penelitian ini, menunjukkan bahwa penduduk dusun VI Desa Tanjung Anom bahwa sejumlah 38 orang ditemukan score lebih dari empat belas gejala-gejala dari strees $(57,6 \%)$ dan yang lain responden menjukkan kurang dari empat belas dari gejala-gejala strees sejumlah 28 orang (42.4\%) dengan dilaksanakan uji korelasi Product Moment dari Pearson hasil korelasinya negatif cukup lemah dengan sangat sifnifikan (r;-0.457;p:0.000)

Hasil penelitian tersebut juga sesuai dengan penelitian yang dilakukan oleh Setyawati (2008) .Korelasi antara tingkat strees dengan kemunduran dari segi fisik, seorang penderita diabetes mellitus pada umumnya juga mengalami kemunduran dari segi emosional. Segi emosional tersebut meliputi sikap menyangkal, obsesif, marah, dan takut, yang semuanya merupakan sikap yang nampak negatif. Banyak orang yang menyangkal sewaktu mengetahui dirinya menyandang diabetes, dan tidak mau menerima kenyataan bahwa ia harus menjalani kehidupan sebagai penyandang diabetes.

.Tingkat stres yang dialami oleh penderita diabetes mellitus diakibatkan oleh adanya perubahan-perubahan dalam dirinya yang bersifat fisik maupun psikologis. Stres yang disertai oleh sikap-sikap emosional lainnya berdampak pada dipatuhi atau tidak dipatuhinya penatalaksanaan pengobatan diabetes oleh penderita diabetes. Semakin tinggi stress, maka semakin banyak pula permasalahanpermasalahan emosional yang dialami oleh penderita diabetes mellitus, dimana kondisi ini berhubungan dengan melemahnya ketaatan penderita diabetes dalam mematuhi penatalaksanaan pengobatan diabetes mellitus, sehingga kadar gula darahnya akan cenderung meningkat.

. Perubahan yang terjadi dalam kesehatan fisik, spiritual, emosional, seksual, kekeluargaan dan sosiokultural, dapat menyebabkan stress. Stress dapat mengganggu cara seseorang menyerap realitas, menyelesaikan masalah, berpikir secara umum, dan hubungan seseorang dan cara memiliki.. Setiap perubahan dalam kesehatan dapat menjadi stressor yang 
mempengaruhi konsep diri. Stressor konsep diri adalah segala perubahan nyata yang mengancam identitas, citra tubuh, harga diri dan perilaku peran (Perry \& Potter, 2005). Diagnosis diabetes dapat membuat seseorang menjadi kehilangan kontrol. Semua atau sebagian klien mengalami kehilangan fleksibilitas.hidup mengikuti perintah dan rutinitas yang harus diikuti. Peristiwa-peristiwa pasti yang mengelilingi dibetes dapat diprediksi. Mendapatkan suntikan insulin dan tidak makan untuk beberapa jam menyebabkan hipoglikemi.

Kontrol yang buruk terhadap penyakit akan mengakibatkan komplikasi dan kematian lebih cepat. Stress pada klien diabetes merupakan kumpulan tuntutan untuk hidsup dengan normal. Klien harus bisa mengintegrasikan tuntutan dari DM menjadi keseharian dan adanya jadwal rekreasi sambil menjaga gula darah tetap stabil (Ignatavicius \& Workman, 2006). Penelitian lain yang terkait adalah tentang efek psikologis yang ditimbulkan oleh diabetes juga didukung oleh penelitian yang dilakukan oleh Winasis(2009), dengan judul yang sama dengan dengan Saraswati yaitu hubungan antara konsep diri dan tingkat depresi pada penderita diabetes .

\section{Analisis Regresi Linier Sederhana}

Hasil uji regresi linier diet sehat seimbang zat protein memberikan engaruh signifikan terhadap kejadian penyakit tidak menular diabetes $(\mathrm{p} ; 0.000)$ dari hasil ini variabel konsumsi karbohidrat dengan uji regresi linier kedua korelasi toleransi dengan kadar glukosa darah pada saat uji bersama-sama antara konsumsi protein dengan karbohidrat kalah terhadap kejadian penyakit tidak menular diabetes meletus oleh pengaruh variabel bebas dari sepuluh variabel I dependen. Hasil koefisien regresi linier ternyata konsumsi protein memberikan pengaruh postif sangat kuat dari kedua variabel tersebut yang sangat berpengaruh terhadap kejadian diabetes dibandingkan konsumsi karbohidrat frekuensi durasi lebih sering lebih lima kali sehari, jika dibuat dalam persamaan regresi, maka dapat diperoleh sebagai berikut; kejadian penyakit tidak menular diabetes meletus $0.111+0.889$ ( konsumsi protein ), hal ini berarti setiap peningkatan frekuensi durasi konsumsi protein 8,89 kali per hari akan menimbulkan gangguan konsentrasi kadar glukosa darah tubuh sehingga akan terjadilah prevalensi kejadian diabetes meletus.

\begin{tabular}{|c|c|c|c|c|c|}
\hline \multirow[t]{2}{*}{ Model } & \multicolumn{2}{|c|}{$\begin{array}{c}\text { Unstandardized } \\
\text { Coefficients }\end{array}$} & \multirow{2}{*}{$\begin{array}{c}\text { Standardized } \\
\text { Coefficients } \\
\text { Beta }\end{array}$} & \multirow[b]{2}{*}{1} & \multirow[b]{2}{*}{ Sia. } \\
\hline & B & Std Error & & & \\
\hline (Constant) & .111 & 039 & I & 2.828 & .006 \\
\hline $\begin{array}{l}\text { Konsumsi } \\
\text { Protein }\end{array}$ & .889 & 092 & .770 & 9.648 & .000 \\
\hline
\end{tabular}

Tabel:1; Analisis Regresi Linier Sederhana

Berdasarkan analisis hubungan antara stres dengan kejadian diabetes didapatkan bahwa ada hubungan yang signifikan antara stres dengan kejadian diabetes Adanya peningkatan risiko diabetes pada kondisi stres disebabkan oleh produksi hormone kortisol secara berlebihan saat seseorang mengalami stres. Produksi kortisol yang berlebih ini akan mengakibatkan sulit tidur, depresi, tekanan darah merosot, yang kemudian akan membuat individu tersebut menjadi lemas, dan nafsu makan berlebih. Oleh karena itu, ahli nutrisi biologis Shawn Talbott menjelaskan bahwa pada umumnya orang yang mengalami stres panjang juga akan mempunyai kecenderungan berat badan yang berlebih, yang merupakan salah satu faktor risiko diabetes melitus (Siagian,2012).

\section{KESIMPULAN}

Berdasarkan hasil penelitian ini maka dapat disimpulkan bahwa berbagai variabel independen yang berkolerasi dengan kejadian penyakit tidak menular diabetes meletus yang positif sangat kuat signifikan sebagai determinan perilaku Cek kesehatan meliputi (indeks massa tubuh, lingkar perut tensi darah kolesterol ), Rajin olahraga/aktifitas fisik. Variabel yang berkorelasi positf kuat dengan signifikan yaitu; diet sehat seimbang karbohidrat,protein lemak dan serat sayuran dan buah buahan, sedangkan determinan korelasi positif cukup kuat dengan signifikan istirahat tidur dan korelasi negatil lemah signifikan control strees, sedangkan tidak berkorelasi positif lemah dengan tidak signifikan terhadap kejadian penyakit tidak menular diabetes meletus.Variabel yang paling dominan terhadap determinan terhadap kejadian diabetes 
meletus itu adalah Cek kesehatan Indeks massa tubuh,lingkar perut tensi darah.kolesterol, Rajin olahraga/aktifitas fisik diet tidak sehat seimbang lemak serat sayur dan buah-buahan .

\section{Daftar Pustaka}

Arora SK, Mc Farlane SI. The Case For Low Carbohydratediets in Diabetes Management. Nutr \& Metab.2005.

Almatsier S. Prinsip Dasar Ilmu gizi. Jakarta: Gramedia Pustaka Utama; 2009.

Adhi,Bayu.T1, Rodiyatul F. S. dan Hermansyah,2011. An Early Detection Method of Type-2 Diabetes Mellitus in Public Hospital. Telkomnika, Vol.9, No.2.

Agustina, Tri ,2009.Gambaran Sikap Pasien Diabetes Melitus Di Poli Penyakit Dalam RSUD

Askandar Tj,2013 DM dan Macam -macam Diet Diabetes, Air langga University Press Surabaya

Adhi,Bayu.T1, Rodiyatul F. S. dan Hermansyah,2011. An Early Detection Method of Type-2 Diabetes Mellitus in Public Hospital. Telkomnika, Vol.9, No.2.

Depkes RI,2014 .Peran Diet dalam Penanggulangan Diabetes ,Diren Bina Kesmas Jakarta

Dunanty, S. 2012 Indikator Perilaku Kesehatan,Sehat Skala Nasional ( Merokok ) Otot Pola makan yang Baik,Lakukan aktifitas/Olahraga,Jakarta

Jafar,Nurhaedar,2011.Sindrom Metabolik di Indonesia Ombak,Yogjakarta.

Dr.Moewardi Surakarta Terhadap Kunjungan Ulang Konsultasi Gizi. KTI D3. Fakultas Ilmu Kesehatan Universitas Muhammadiyah Surakarta, Surakarta.

Edgren,A.R. Diabetes Mellitus, Health Sites, Inc.653 West 23rd Street; Panama City. 2004;

Gabbard GO,Pysychoanalysis in;Kaplan H.Saddock B.edditors Comprehensive textbook of psychiatry vol $17^{\text {th }}$ ed,Philadelphia Lippincot Williams,2010

Gibney, Michael J., et al., 2009. Gizi Kesehatan Masyarakat (Public Health Nutrition) alih bahasa, Hartono Andry. Jakarta: EGC.

Gropper SS, Smith JL, Groff JL. Advance Nutrition and Human Metabolism. 4th ed. Australia: ThomsonWadsworth. 2005; 72- 83,108-19. 15. Willet WC, Manson J, Liu S. Glycemic Index, Glycemicload and Risk of Type 2 Diabetes. Am S Clin Nutr. 2005.

Hiswani,2010, Penyuluhan Kesehatan pada penderita Diabetes meletus ,FK USU Medan

Hawari, 2001. Manajemen Stres, Cemas, dan Depresi. Jakarta:FKUI

Ignatavicius, D.D., and Workman, M.L., 2006. Medical surgical nursing 5th Ed. St Louis, er Saunders. Missouri: Elsevi

Instansi Gizi RSSA., 2008. Buku Pedoman Praktis Diagnosa Gizi dalam Proses Asuhan Gizi Terstandar.

Ignatavicius, D.D., and Workman, M.L., 2006. Medical surgical nursing 5th Ed. St Louis, er Saunders. Missouri: Elsevi

Instansi Gizi RSSA., 2008. Buku Pedoman Praktis Diagnosa Gizi dalam Proses Asuhan Gizi Terstandar

Indraswari, Wiwi.2010. Hubungan Indeks Glikemik Asupan Makanan Dengan Kadar Glukosa Darah Pada Pasien Rawat Jalan Diabetes Mellitus Di RSUD Dr. Wahidin Sudirohusodoi Fakultas Kesehatan Masyarakat, Universitas Hasanuddin, Makassar. Isniati, 2003, Hubungan Tingkat Pengetahuan Penderita Diabetes Militus Dengan Keterkendalian Gula Darah Di Poliklinik Rs Perjan Dr. M. Djamil

Isniati, 2003, Hubungan Tingkat Pengetahuan Penderita Diabetes Militus Dengan Keterkendalian Gula Darah Di Poliklinik Rs Perjan Dr. M. Djamil Padang Tahun. Jurnal Kesehatan Masyarakat. 
Iman Soeharta, 2014 , searangan jantung dan stroke Hubungannya dengan Lemak dan Kolesterol. Ed II PR GrAMEDIA Pustaka Jakarta.

Irawan,Dedi, 2010,Prevalensi dan factor Resiko Kejadian Diabetes Meletus Tipe 2 di Daerah Urban Indonesia. UI Jakarta.

Juleka. Hubungan Pola Makan dengan Pengendalian Kadar Glukosa Darah Pengidap Diabetes Melitus Tipe 2 Rawat Jalan Di RSU Gunung Jati Cirebon Yogyakarta: Universitas Gadjah Mada; 2015.

Jazilah. Hubungan Tingkat Pengetahuan, Sikap dan Praktik(PSP)Penderita Diabetes Melitus Mengenai Pengelolaan DiabetesMelitus dengan Kendali Kadar Glukosa Darah; Yogyakarta: Program Studi IlmuKesehatan Masyarakat Universitas Gadjah Mada; 2012.

Lingga L. Bebas Diabetes Tipe-2 Tanpa Obat Jakarta: AgroMedia Pustaka; 2012.

Kementerian kesehatan 2010 Petunjuk Teknis Pengukuran Faktor Resiko Diabetes Meletus

Kemenkes RI (2014). Buku Pintar Posbindu PTM Seri 4 Upaya Pengendalian Faktor Risiko PTM.

P. and Burke, K., 2008. Medical Surgical Nursing Critical Thinking in Client Care 4th ed. Canada: Pearson Education, Inc. Lisdiana. 1997.

Rudijanto, A. 2010. Pencegahan dan Penatalaksanaan Diabetes Mellitus melalui Pendekatan Komunitas dalam pidato pengukuhan Jabatan Guru Besar dalam Ilmu Penyakit Dalam Endokrin pada FK Unibraw. Malang.

Mohjuarno.2009. Makalah Kontenporer Konsentrasi Epidemiologi Pasca Sarjana: Penanggulangan Diabetes Melitus. Makassar :Universitas Hasanuddin.

Murwani, Arita dan Afifin Sholeha, 2007. Pengaruh Konseling Keluarga Terhadap Perbaikan Peran Keluarga Dalam Pengelolaan Anggota Keluarga Dengan Dm Di Wilayah Kerja Puskesmas
Kokap I Kulon Progo Medika Yogyakarta..

Dr.Moewardi Surakarta Terhadap Kunjungan Ulang Konsultasi Gizi. KTI D3. Fakultas Ilmu Kesehatan Universitas Muhammadiyah Surakarta, Surakarta.

Nadesul, Hendrawan. 2002. 428 Jawaban untuk 25 Penyakit Manajer dan Keluhan-keluhan Orang Mapan. Kompas.

\section{Perkeni.2011. Empat Pilar Pengelolaan Diabetes}

P. and Burke, K., 2008. Medical Surgical Nursing Critical Thinking in Client Care 4th ed. Canada: Pearson Education, Inc. Lisdiana. 1997.

Qurratuaeni. Faktor-faktor yang Berhubungan dengan Terkendalinya Kadar Gula Darah pada Pasien Diabetes Melitus di Rumah Sakit Umum Pusat (RSUP) Fatmawati Jakarta; 2009

Rakhmadany, dkk. 2010. Makalah Diabetes Melitus. Jakarta : Universitas Islam Negeri

Riskesdas. Riset Kesehatan Dasar (Riskesdas) Laporan Provinsi Sulawesi Selatan. Badan Penelitian dan Pengembangan Kesehatan: Departemen Kesehatan Republik Indonesia; 2007

Rudijanto, A. 2010. Pencegahan dan Penatalaksanaan Diabetes Mellitus melalui Pendekatan Komunitas dalam pidato pengukuhan Jabatan Guru Besar dalam Ilmu Penyakit Dalam - Endokrin pada FK Unibraw. Malang.

Rakhmadany, dkk. 2010. Makalah Diabetes Melitus. Jakarta : Universitas Islam Negeri

Sutanto T. Diabetes Deteksi, Pencegahan, Pengobatan. Yogyakarta: Buku Pintar; 2013

$\begin{aligned} & \text { Shahab, } \text { Alwi,2006.Diagnosis } \\ & \text { Penatalaksanaan Diabetes } \\ & \text { Melitus (Disarikan Dari Konsensus } \\ & \text { Pengelolaan Diabetes Melitus Di } \\ & \text { Indonesia : Perkeni 2006).Subbagian }\end{aligned}$


Endokrinologi Metabolik, Bagian Ilmu Penyakit Dalam, Fk Unsri/ Rsmh Palembang, Palembang.

Sutanto T. Diabetes Deteksi, Pencegahan, Pengobatan. Yogyakarta: Buku Pintar; 2013

Shahab, Alwi,2006.Diagnosis Dan Penatalaksanaan Diabetes Melitus (Disarikan Dari Konsensus Pengelolaan Diabetes Melitus Di Indonesia : Perkeni 2006).Subbagian Endokrinologi Metabolik, Bagian Ilmu Penyakit Dalam, Fk Unsri/ Rsmh Palembang, Palembang.

Subroto, Ahkam, 2006. Ramuan Herbal Untuk Diabetes Mellitus. Penebar Swadaya, Jakarta.

Sulistijani, Dina Agoes, 2012. Sehat Dengan Menu Berserat. Trubus Agriwidya, Jakarta.

Smeltzer dan Bare, 2008. Brunner and Suddarh's textbook of medical - surgical nursing 8th ed, Philadelphia: Lippincott Williams \& Wilkin

Soeparman. 1987. Ilmu Penyakit Dalam, Jilid I, Edisi II, Jakarta: Balai Penerbit FKUI.

Suhardjo. 1996. Berbagai Cara Pendidikan Gizi. Jakarta: Bumi Aksara. Supariasa, IDN., dkk. 2002. Penilaian Status Gizi, Jakarta: Penerbit EGC

Soeparman. 1987. Ilmu Penyakit Dalam, Jilid I, Edisi II, Jakarta: Balai Penerbit FKUI.

Suhardjo. 1996. Berbagai Cara Pendidikan Gizi. Jakarta: Bumi Aksara. Supariasa, IDN., dkk. 2002. Penilaian Status Gizi, Jakarta: Penerbit EGC

\section{Trisnawati,Shara K,dkk 2013 ,Faktor Resiko Diabetes Meletus Tipe 2 di Puskesmas Kecamatan Cengkareng Jakarta barat tahun 2012, Jurnal Ilmiah Kesehatan Vol 5}

Tjeyan, Suryadi R.M, 2007.Risiko Penyakit Diabetes Mellitus Tipe 2 Di Kalangan Peminum Kopi Di Kotamadya Palembang Tahun 2006-2007
Utami, Prapti dan Tim Lentera, 2014. Terapi Jus untuk Diabetes Mellitus. Agro Media Pustaka, Jakarta.

Yunir, 2007 Mengenal penyakit Diabetes FKUI, Jakarta

WHO. Prevalention of Diabetes Mellitus. 218 Andi Mardhiyah Idris : Pola Makan dengan Kadar Glukosa Darah Pasien DM Tipe 2 Report of Joint WHO/FAO.

Waspadji,dkk.2004. Pedoman Diet Diabetes Mellitus. Balai Pustaka. FK.UI.Jakarta

Willet WC, Manson J, Liu S. Glycemic Index, Glycemicload and Risk of Type 2 Diabetes. Am S Clin Nutr. 2005; 76(1):274S-80S.

Waspadji, al e. Indeks Glikemik Berbagai Makanan Indonesia. Jakarta: Universitas Indonesia; 2013.

Waspadji, Sarwono dkk., 2009. Pedoman Diet Diabetes Melitus. Jakarta: FKUI.

WHO, 1999. Defenition, Diagnosis and Classification of Diabetes Melitus and Its Complication.

Waspada terhadap Kelebihan dan Kekurangan Gizi. Jakarta: Trubus Agriwidya. Persagi. 1999. Penuntun Diit. Jakarta: PT Gramedia Pustaka Utama 
